\title{
EFFECT OF MATING METHOD, SEX AND BIRTH TYPE ON GROWTH OF LAMBS
}

\author{
Z. Ilić ${ }^{1}$, A. Jevtić-Vukmirović ${ }^{2}$, M. P. Petrović ${ }^{3}$, V. Caro Petrović ${ }^{3}$, B. \\ Milošević $^{1}$, Z. Spasić ${ }^{1}$, B. Ristanović ${ }^{1}$ \\ ${ }^{1}$ Faculty of Agriculture, Lesak \\ ${ }^{2}$ High School Agricultural Food, Prokuplje, Serbia \\ ${ }^{3}$ Institute for Animal Husbandry, Belgrade-Zemun \\ Corresponding author: zoran.ilic@pr.ac.rs \\ Original scientific paper
}

\begin{abstract}
Estrus synchronization methods was use to control the reproductive traits of sheep, as well as bringing more females at the same stage of estrus and ovulation. According to the points mentioned above, the aim of the present study was to investigate and compare mating method and influence of fixed factors on birth and weaning weight of lambs. Statistical analysis showed that exist difference in the body weights between genotypes of lambs. In the first group, the difference in weight of lambs at birth, regardless of mating method was not significant (P> $0.05)$, while in the second group, the difference was slightly significant $(\mathrm{P}<0.05)$. As for the birth type,sex and within the same genotype, there was a statistical significance $(\mathrm{P}<0.05)$ between singles obtained naturally, between the triplets obtained naturally and between triplets received hormonal method. All the differences between body weight at 30 days (mating method, sex and birth type under the same genotype) were statistically significant $(\mathrm{P}<0.05)$. The determined differences in the body weights at 60 days (sex, mating method and type of birth under the same genotype) were statistically significant $(\mathrm{P}<0.05)$. The results showed that the differences (mating method, sex and type of birth under the same genotype) were statistically significant $(\mathrm{P}<0.05)$, except in between body weight at 90 days in twins among two genotypes obtained by natural method, which were not statistically significant $(\mathrm{P}>0.05)$.
\end{abstract}

Key words: sheep, mating method, body weight, lamb

\section{Introduction}

In order to boost the production of sheep and technological process of organizing principles in industry, science has made efforts to successfully manage the process of breeding ewes. Today, in many countries, including ours, estrus synchronization methods was use to control the reproductive traits of sheep, as well as bringing more females at the same stage of estrus and ovulation. This method 
enabled the two or three lambs a year for two years, with the aim of increasing meat production. Petrovic (2007) point out that the use of proper hygiene in the reproduction of sheep, breeding age, environmental conditions, qualitative and quantitative nutrition, prevention and treatment are the key factors. The same authors argue that, the recognition of estrus and time of admission is the essential part of the concept, and therefore the pregnancy of animals. For more than half a century attempts have been made to synchronize the period of sexual receptivity, or estrus, in farm animals. Synchronization of estrus can save labor and is a key component in artificial insemination (AI) programs. Synchronizing estrus during the normal breeding season provides a means for producers to schedule the lambing period, concentrating labor needs into a short frame of time. Estrous synchronization also can help in improving and the uniformity of the lamb crop for market, Knights et al,(2001). Estrus synchronization (ES) in goats and sheep is achieved by control of the luteal phase of the estrous cycle, either by providing exogenous progesterone or by inducing premature luteolysis. The latter approach is not applicable during seasonal anestrus, whereas exogenous progesterone in combination with gonadotropin can be used to induce and synchronize estrus in anovular does and ewes, S. Wildeus (1999). Successful estrus synchronization programs have a key role in lambing rate efficiency and profitability of sheep holders in semi-intensive production systems (Knights et al., 2001). Using different intravaginal devices impregnated with $\mathrm{P} 4$ or synthetic progestogens has been extended all over the world. Controlled internal drug release (CIDR) device impregnated with $300 \mathrm{mg} \mathrm{P} 4$ and intravaginal sponges containing with $60 \mathrm{mg}$ medroxyprogesterone acetate (MAP) or $40 \mathrm{mg}$ fluoroprogesterone acetate (FGA) are two main intravaginal devices that are used vastly for ewes estrus synchronization (Ungerfeld and Rubianes, 2002). PGF2 $\alpha$ and/or its analogue are luteolytic factors and according to its role in regression mechanism of corpus luteum (Turk et al., 2008), double injections (9 to 11 days interval) of PGF2 $\alpha$ is common for ewes' estrus synchronization (Atamani and Akoz, 2006; Wildeus 2000). Also, Dixon et al. (2006) used progesterone and/or its analogue treatment and reported greater estrus observation in progesterone-PGF $2 \alpha$ combination treated ewes than those received PGF2 $\alpha$ alone. Combination of PMSG and P4 impregnated intravaginal devices causes readily estrus synchronization (Romano 2004). PMSG treatment reduces the interval between the onset of estrus and ovulation (Dogan and Nur, 2006), also in no PMSG received ewes, ovulations occurs later (Barrett et al., 2004). One dose of PMSG can stimulate follicular development and higher ovulation rate in ewes (Koyuncu and Ozis Alticekic, 2010). Due to the importance of PMSG in sheep reproduction efficiency and injection of 500 IU PMSG with $40 \mathrm{mg}$ of FGA for estrus synchronization in breeding season, $87 \%$ of treated ewes exhibited overt sign of estrus when compared with $48 \%$ in the control group (Langford, 1982) or CIDR removal until the estrus onset was shorter in progesterone-PGF2 $\alpha$. Obtained results by Dogan and Nur (2006) demonstrated 
that the interval between Sponge progesterone - PGF2 $\alpha$ combination treated ewes than those that received progesterone alone. One dose of PMSG can stimulate follicular development and higher ovulation rate in ewes (Koyuncu and Ozis Alticekic, 2010). Estrous synchronization is a valuable management tool which has been successfully employed to enhance reproductive efficiency, particularly in ruminants (Kusina et al., 2000). In small ruminants, estrous synchronization is achieved either by reducing the length of the luteal phase of the estrous cycle with prostaglandin F2 $\alpha$ or by extending the cycle artificially with exogenous progesterone or more potent progestagens (Jainudeen et al., 2000; Kusina et al., 2000). As prostaglandin treatment is limited to the breeding season, different protocols of estrous synchronization using progestin's have been introduced (Ainsworth and Wolynetz, 1982; Godfrey et al., 1997; Rosado et al., 1998). Estrus synchronization by CIDR method was as effective as Sponge (MAP) and PGF2 $\alpha$ treatment for inducing estrus. Also, CIDR treated ewes exhibited overt signs of estrus earlier than other treatment groups, Naderipour et al, (2012). According to the points mentioned above and the importance of estrus synchronization to optimize ewes reproduction efficiency, the aim of the present study was to investigate and compare mating method and influence of fixed factors on birth and weaning weight of lambs.

\section{Materials and Methods}

Investigation of the effect of estrus synchronization was performed on private farm in Vrnjacka Banja.

- The first group of 60 local Pirot ewes mated with ram of Wurttemberg breed of sheep.

- Second group of 60 local Pirot ewes were mated with ram of Improved Pirot breed of sheep.

Within each group 30 sheep were subjected to natural mating and the rest 30 sheep within each group have been utilized for estrus synchronization. The first subgroup of both groups performed the synchronization and the second subgroup of both groups performed the natural mating. One ram was mated for every ten ewes. 
Table 1. Experimental scheme of mating

\begin{tabular}{|l|c|c|c|c|}
\hline Group & \multicolumn{2}{|c|}{ First (1) } & \multicolumn{2}{c|}{ Second (2) } \\
\hline Ram & \multicolumn{2}{|c|}{ Wuerttemberg (W) } & \multicolumn{2}{c|}{60} \\
\hline Number of animals in group & \multicolumn{2}{|c|}{60} & Natural & Synchronize \\
\hline Subgroups & Natural & Synchronize & 30 & 30 \\
\hline No. of animals & 30 & 30 & 3 & 3 \\
\hline No. of rams & 3 & 3 & - & Veramix \\
\hline Used product & - & Veramix & & \\
\hline
\end{tabular}

For induction of estrus synchronization and in sheep experimental group applied the technique of intra vaginal sponges with progestin's (Veramix, Pharmacia \& Upjohn, Belgium) Applicator coated Vaseline on the outside and the inside part, frimly held and introduced into the vagina to the cervix. Rod applicator sponge is pushed forward and then pilled out a tube applicator from the vagina, extracting rod that holds the sponge that carried control setting using a plastic end that protrudes from the vagina. Synchronization of sheep had done in the month of April. Sponges were removed from the vagina 12 days after the application. The first sign of estrus were reported 35 hous after the extraction. The experimental sheep lambing commenced on the $30^{\text {th }}$ of August those that are conceptualized by, or on the $16^{\text {th }}$ September who became pregnant in the next estrus. Before the synchronization of estrus a dose of an anthelmintic treatment and vaccination of sheep against anaerobic bacteria was performed. Determination of the production result based on the body weight have been made for both groups. Recording of body weight started from newborn lambs (birth weight-BW), lambs body weight at 30 days, (BW30), 60 days (BW60) and 90 days (BW90). Statistical analysis was performed by GLM procedure of SPSS package, using the next model:

Yijklm $=\mu+\mathrm{Gi}+\mathrm{Mj}+\mathrm{Bk}+\mathrm{Sl}+\varepsilon \mathrm{ijklm}$,

where

Yijklm $=$ body weight of $\mathrm{m}^{\text {th }}$ lamb of $\mathrm{l}^{\text {th }}$ sex, $\mathrm{kj}^{\text {th }}$ birth type, $\mathrm{j}^{\text {th }}$ mating method, $\mathrm{i}^{\text {th }}$ genotype

$\mu=$ overall population mean

$\mathrm{Gi}=$ effect of genotype(fixed effect -2 classes)

$\mathrm{Mj}=$ effect of mating method (fixed effect -2 classes)

$\mathrm{Bk}=$ effect of birth type (fixed effect -3 classes)

$\mathrm{Sl}=$ effect of sex (fixed effect -2 classes)

eijklm $=$ residual error 


\section{Results and Discussion}

Table 2. The mean value of lambs body weight from birth to 90 days- Wurttemberg, ram, $\mathrm{kg}$

\begin{tabular}{|c|c|c|c|c|c|c|c|c|c|c|}
\hline \multirow{2}{*}{$\begin{array}{l}\text { Mating } \\
\text { method }\end{array}$} & \multirow{2}{*}{$\begin{array}{l}\text { Birth } \\
\text { type }\end{array}$} & \multirow{2}{*}{ Sex } & \multicolumn{2}{|c|}{ BWB } & \multicolumn{2}{|c|}{ BW30 } & \multicolumn{2}{|c|}{ BW60 } & \multicolumn{2}{|c|}{ BW90 } \\
\hline & & & Mean & $\pm \mathrm{SE}$ & Mean & $\pm \mathrm{SE}$ & Mean & $\pm \mathrm{SE}$ & Mean & $\pm \mathrm{SE}$ \\
\hline \multirow{9}{*}{$\mathrm{S}$} & \multirow[t]{2}{*}{ Single } & male & 3,40 & 0.04 & 11,51 & 0.04 & 15,63 & 0.16 & 22,15 & 0.18 \\
\hline & & female & 3,11 & 0.02 & 10,72 & 0.12 & 14,62 & 0.11 & 20,28 & 0.17 \\
\hline & \multicolumn{2}{|c|}{ average } & 3,26 & 0.04 & 11,13 & 0.10 & 15,15 & 0.14 & 21,26 & 0.23 \\
\hline & \multirow[t]{2}{*}{ Twins } & male & 3,09 & 0.15 & 10,40 & 0.12 & 14,84 & 0.24 & 20,28 & 0.24 \\
\hline & & female & 2,91 & 0.09 & 10,14 & 0.15 & 14,28 & 0.27 & 19,53 & 0.39 \\
\hline & \multicolumn{2}{|c|}{ average } & 3,00 & 0.08 & 10,27 & 0.10 & 14,56 & 0.19 & 19,90 & 0.25 \\
\hline & \multirow[t]{2}{*}{ Triplets } & male & 2,65 & 0.11 & 10,13 & 0.15 & 14,40 & 0.23 & 19,57 & 0.39 \\
\hline & & female & 2,38 & 0.14 & 9,31 & 0.17 & 12,77 & 0.66 & 17,59 & 0.54 \\
\hline & \multicolumn{2}{|c|}{ average } & 2,55 & 0.09 & 9,82 & 0.18 & 13,79 & 0.39 & 18,83 & 0.46 \\
\hline \multicolumn{3}{|c|}{ Synchronization- average } & 3,06 & 0.06 & 10,27 & 0.04 & 14,75 & 0.15 & 20,48 & 0.23 \\
\hline \multirow{9}{*}{$\mathrm{N}$} & \multirow[t]{2}{*}{ Single } & male & 3,66 & 0.05 & 11,74 & 0.14 & 16,53 & 0.34 & 22,86 & 0.40 \\
\hline & & female & 3,37 & 0.24 & 11,19 & 0.08 & 16,08 & 0.45 & 22,08 & 0.46 \\
\hline & \multicolumn{2}{|c|}{ average } & 3,55 & 0.04 & 11.53 & 0.11 & 16,36 & 0.27 & 22,57 & 0.31 \\
\hline & \multirow[t]{2}{*}{ Twins } & male & 3,40 & 0.10 & 10,98 & 0.28 & 15,93 & 0.17 & 21,89 & 0.21 \\
\hline & & female & 3,15 & 0.10 & 10,97 & 0.08 & 15,64 & 0.23 & 21,52 & 0.23 \\
\hline & \multicolumn{2}{|c|}{ average } & 3,24 & 0.08 & 10.97 & 0.10 & 15,74 & 0.16 & 21,64 & 0.17 \\
\hline & \multirow[t]{2}{*}{ Triplets } & male & 2,76 & 0.09 & 10,54 & 0.23 & 14,70 & 0.60 & 20,19 & 0.75 \\
\hline & & female & 2,59 & 0.23 & 9,83 & 0.33 & 14,65 & 0.36 & 20,13 & 0.41 \\
\hline & & 2,68 & 0.11 & 10.22 & 0.22 & 14,67 & 0.35 & 20,17 & 0.43 \\
\hline \multirow{2}{*}{\multicolumn{3}{|c|}{$\begin{array}{l}\text { Natural- average } \\
\text { Overall average }\end{array}$}} & 3,27 & 0.06 & 11.09 & 0.11 & 15,82 & 0.18 & 21,79 & 0.23 \\
\hline & & & 3,17 & 0.04 & 10.90 & 0.08 & 15,30 & 0.13 & 21,16 & 0.18 \\
\hline
\end{tabular}

S- synchronization, N-natural

On table 2 showed that the birth weight of single born male lambs and female from natural mating were heavier than the single born male and female lambs from synchronized mating for the same difference of $0.26 \mathrm{~kg}$. The male and female lambs born twin from natural mating were heavier for $0.31 \mathrm{~kg}$ and $0.24 \mathrm{~kg}$. The male and female lambs born triplet were heavier in natural mating with a difference of $0.11 \mathrm{~kg}$ for male lambs and $0.21 \mathrm{~kg}$ for female in synchronized mating. 
Table 3. The mean value of lambs body weight from birth to 90 days-Pirot ram, $\mathrm{kg}$.

\begin{tabular}{|c|c|c|c|c|c|c|c|c|c|c|}
\hline \multirow{2}{*}{$\begin{array}{l}\text { Mating } \\
\text { method }\end{array}$} & \multirow{2}{*}{ Birth type } & \multirow{2}{*}{ Sex } & \multicolumn{2}{|c|}{ BWB } & \multicolumn{2}{|c|}{ BW30 } & \multicolumn{2}{|c|}{ BW60 } & \multicolumn{2}{|c|}{ BW90 } \\
\hline & & & Mean & $\pm \mathrm{SE}$ & Mean & $\pm \mathrm{SE}$ & Mean & $\pm \mathrm{SE}$ & Mean & $\pm \mathrm{SE}$ \\
\hline \multirow{9}{*}{$\mathrm{S}$} & \multirow[t]{2}{*}{ Single } & male & 3,38 & 0.04 & 11,13 & 0.07 & 15,71 & 0.10 & 21,61 & 0.17 \\
\hline & & female & 3,09 & 0.03 & 10,44 & 0.09 & 14,73 & 0.06 & 20,12 & 0.12 \\
\hline & \multicolumn{2}{|c|}{ average } & 3,23 & 0.04 & 10,77 & 0.09 & 15,20 & 0.12 & 20,83 & 0.19 \\
\hline & \multirow[t]{2}{*}{ Twins } & male & 3,23 & 0.19 & 10,55 & 0.21 & 14,90 & 0.18 & 20,25 & 0.31 \\
\hline & & female & 2,86 & 0.08 & 9,98 & 0.09 & 14,50 & 0.19 & 19,63 & 0.21 \\
\hline & \multicolumn{2}{|c|}{ average } & 3,01 & 0.10 & 10,21 & 0.13 & 14,66 & 0.14 & 19,88 & 0.19 \\
\hline & \multirow[t]{2}{*}{ Triplets } & male & 2,51 & 0.05 & 9,92 & 0.13 & 14,12 & 0.24 & 18,75 & 0.27 \\
\hline & & female & 2,27 & 0.08 & 9,52 & 0.17 & 13,30 & 0.23 & 17,75 & 0.46 \\
\hline & \multicolumn{2}{|c|}{ average } & 2,39 & 0.07 & 9,72 & 0.13 & 13,71 & 0.24 & 18,25 & 0.33 \\
\hline \multicolumn{3}{|c|}{ Synchronization- total } & 3,04 & 0.06 & 10,47 & 0.09 & 14,83 & 0.12 & 20,19 & 0.19 \\
\hline \multirow{9}{*}{$\mathrm{N}$} & \multirow[t]{2}{*}{ Single } & male & 3,57 & 0.02 & 11,44 & 0.18 & 16,20 & 0.17 & 22,70 & 0.23 \\
\hline & & female & 3,46 & 0.06 & 10,91 & 0.14 & 15,49 & 0.32 & 21,36 & 0.40 \\
\hline & \multicolumn{2}{|c|}{ average } & 3,51 & 0.03 & 11,17 & 0.13 & 15,85 & 0.19 & 22,03 & 0.27 \\
\hline & \multirow[t]{2}{*}{ Twins } & male & 3,30 & 0.06 & 11,08 & 0.09 & 15,65 & 0.27 & 21,66 & 0.29 \\
\hline & & female & 3,07 & 0.10 & 10,37 & 0.14 & 15,45 & 0.24 & 21,04 & 0.24 \\
\hline & \multicolumn{2}{|c|}{ average } & 3,20 & 0.06 & 10,76 & 0.11 & 15,56 & 0.18 & 21,38 & 0.20 \\
\hline & \multirow[t]{2}{*}{ Triplets } & male & 2,70 & 0.05 & 9,66 & 0.12 & 15,33 & 0.19 & 20,28 & 0.22 \\
\hline & & female & 2,53 & 0.08 & 9,12 & 0.10 & 12,01 & 0.29 & 17,17 & 0.32 \\
\hline & \multicolumn{2}{|c|}{ average } & 2,59 & 0.07 & 9,30 & 0.19 & 13,12 & 0.10 & 18,21 & 0.20 \\
\hline \multicolumn{3}{|c|}{ Natural- average } & 3,29 & 0.05 & 10.83 & 0.10 & 15,51 & 0.17 & 21,43 & 0.21 \\
\hline \multicolumn{3}{|c|}{ Overall average } & 3,17 & 0.04 & 10,66 & 0.07 & 15,19 & 0.11 & 20,84 & 0.16 \\
\hline
\end{tabular}

S- synchronization, N-natural

From table 2, can also be seen, that the body weight of male lambs and female lambs from natural mating at 30 days were heavier in all birth type with differences of: $0.23 \mathrm{~kg} ; 0.47 \mathrm{~kg}, 0.58 \mathrm{~kg} ; 0.83 \mathrm{~kg}, 0.41 \mathrm{~kg} ; 0.52 \mathrm{~kg}$. At 60 days, lambs from natural mating were heavier in both sexes as well as in all birth types the differences were: $0.9 \mathrm{~kg} ; 1.46 \mathrm{~kg}, 1.09 \mathrm{~kg} ; 1.36 \mathrm{~kg}, 0.3 \mathrm{~kg} ; 1.88 \mathrm{~kg}$. Same at 90 days, lambs from natural mating were dominant in weight in all ages and in both sexes. The differences were as follows : $0.71 \mathrm{~kg} ; 1.8 \mathrm{~kg}, 1.61 \mathrm{~kg} ; 1.99 \mathrm{~kg}, 0.67$ $\mathrm{kg} ; 2.54 \mathrm{~kg}$.

As shown in table 3, the birth weight of male and female lambs from natural mating were heavier than synchronized in all birth type.. The differences were: $0.19 \mathrm{~kg} ; 0.37 \mathrm{~kg}, 0.07 \mathrm{~kg} ; 0.21 \mathrm{~kg}, 0.19 \mathrm{~kg} ; 0.26 \mathrm{~kg}$ respectively. Yilmaz and Altin, (2011) birth type and the sex of the lambs were found to significantly affect birth weight, which is an important factor in lamb production which was in accordance with ours. As can be seen on tables 2 and 3 indicated that generally synchronized mating affected the body weight of lambs from birth to 90 days. 
Özbey and Esen (2000) quoted that estrus synchronization usually increases the number, but reduces the birth weight of lambs, which is related with the results we obtained. The average birth weight in our study was $(3.17 \mathrm{~kg})$ was lower than the average found by other studies performed by some authors on different genotypes Chios $\times$ Akkaraman F1, $4.72 \mathrm{~kg}$; Kivırcık $\times$ Akkaraman F1, $4.75 \mathrm{~kg}$; Chios $\times$ (Kıvırcık $\times$ Morkaraman) F1, $4.45 \mathrm{~kg}$; Kivircık $\times($ Chios $\times$ Morkaraman) F1, 4.25 kg; crossbred lambs (Akcapinar et al .; 2000, Ozbey and Esen 2000); Kivircik lambs under half-intensive conditions, $3.69 \mathrm{~kg}$ (Altine et al., 1998,); and Akkaramans, Merino, and their crosses under village conditions, $3.74 \mathrm{~kg}$ (Thieme et al., 1999) but almost similar with the result $(3.18 \mathrm{~kg})$ obtained by Yilmaz and Altin, (2011).

At 30 days, the lambs born singles and twins were heavier from natural mating but born triplets were heavier from synchronized in both sexes. Differences in weight: $0.31 \mathrm{~kg} ; 0.47 \mathrm{~kg}, 0.53 \mathrm{~kg} ; 0.39 \mathrm{~kg}, 0.26 \mathrm{~kg} ; 0.4 \mathrm{~kg}$.

The lambs at 60 and 90 days, female born triplets were heavier from synchronized but lambs born singles and twins in both sexes and the male born triplets were heavier from natural mating. The weight differences were as follows: $0.49 \mathrm{~kg} ; 0.76 \mathrm{~kg}, 0.75 \mathrm{~kg} ; 0.95 \mathrm{~kg}, 1.21 \mathrm{~kg} ; 1.29 \mathrm{~kg}$ and $1.09 \mathrm{~kg} ; 1.24 \mathrm{~kg}, 1.41$ $\mathrm{kg} ; 1.41 \mathrm{~kg}$ (same differences in both sexes), $1.53 \mathrm{~kg} ; 0.58 \mathrm{~kg}$. Our results were similar with results of Petrovic et al.(2011).

Statistical analysis of our results showed that exist difference in the body weights between groups of lambs depending of investigated factors. In the first group, the difference in weight of lambs at birth, with regard of mating method was not significant $(\mathrm{P}>0.05)$, while in the second group, the difference was statistically significant $(\mathrm{P}<0.05)$. As for the birth type, and within the same group, there was a statistical significance $(\mathrm{P}<0.05)$ between singles obtained naturally, between the triplets obtained naturally and between triplets received hormonal method.

All the differences between male body weight at 30 days (mating method, sex and birth type under the same genotype) were statistically significant $(\mathrm{P}<0.05)$.

The determined differences in the body weights at 60 days (between genotypes, mating method, sex and type of birth under the same genotype) were statistically significant $(\mathrm{P}<0.05)$.

The results showed that the differences (mating method, sex and type of birth under the same genotype) were statistically significant $(\mathrm{P}<0.05)$, except in between body weight at 90 days in twins among two genotypes obtained by natural method, which were not statistically significant $(\mathrm{P}>0.05)$.

\section{Conclusion}

Based on the results obtained can be concluded that sex had a significant effect on body weight of lambs in all ages regardless of mating method. The estrus 
synchronization can increase the number of offspring, but reduces the birth weight of lambs. Generally, natural mating shows dominance in body growth in all ages of lambs.

\section{Acknowledgment}

Research was financed by the Ministry of Education and Science of Republic of Serbia under the projects TR31001 and TR31053.

\section{Uticaj metoda oplodnje genotipa, pola i tipa rođenja na porast jagnjadi}

Z. Ilić, A Jevtić-Vukmirović, M P. Petrović, V. Caro Petrović, B. Milošević, Z. Spasić, B. Ristanović

\section{Rezime}

Metod sinhronizacije estrusa se koristi da kontroliše reproduktivne osobine ovaca. Cilj ovog rada bio je da se ispita i uporedi način parenja i uticaj osnovnih fiksnih faktora na masu jagnjadi. Statistička analiza je pokazala da je razlika telesne mase između grupa jagnjadi na rođenju bila statistički značajna. U prvoj grupi, razlika u masi jagnjadi na rođenju, zavisno od načina oplodnje nije bila značajna $(P>0,05)$, dok je u drugoj grupi, razlika statistički značajna $(P<0,05)$. Što se tiče tipa rođenja, a u okviru istog genotipa, postoji statistička značajnost ( $\mathrm{P}$ $<0,05)$ između jedinaca dobijenih prirodno, između prirodno dobijenih trojki i između trojke dobijenih hormonskim metodom. Sve razlike između masa tela muških grla sa 30 dana (načinu oplodnje, tipa rođenja i u okviru istog genotipa) su statistički značajne $(\mathrm{P}<0,05)$. Utvrđene razlike u telesnoj masi sa 60 dana su takođe statistički značajne $(\mathrm{P}<0,05)$. Rezultati su pokazali da su razlike između genotipova pod uticajem fiksnih faktora statistički značajne $(\mathrm{P}<0,05)$, osim između telesne mase sa 90 dana kod blizanaca $(\mathrm{P}>0,05)$.

\section{References}

AINSWORTH, L. AND M. S. WOLYNETZ. (1982): Synchronization of estrus and reproductive performance of ewes treated with synthetic progestagens administered by subcutaneous ear implant or by intravaginal sponge pessary. J. Anim. Sci. 54: 1120-1127. 
AKCAPINAR, H., OZBEYAZ C, UNAL, N., AVCI. M. (2000): The possibilities of developing dam and sire lines using Akkaraman, Sakız and Kivircık Sheep breeds for lamb production I. Fertility in Akkaraman sheep, survival rate and growth characteristics of Sakız $\times$ Akkaraman F1 and Kivirc1k $\times$ Akkaraman F1 lambs. Türk Veterinerlik ve Hayvanc1lık Dergisi.24:71-79.

ALTINEL, A., EVRIM, M., OZCAN, M., BASPINAR, H., DELIGOZOĞLU, F.(1998): Studies on possibility of producing high quality lambs by crossbreeding among Sakiz, Kivircik and German Black Headed Mutton sheep. Turk J. Vet. Anim. Sci. 22: 257- 265.

ATAMANI M.B, AKOZ M. (2006): GnRH-PGF2 $\alpha$ and PGF2 $\alpha-P G F 2 \alpha$ synchronization in Akkarman cross-breed sheep in the breeding season. Bull Vet Inst Pulawy. 50: 101-104.

BARRETT D.M, BARTLEWSKI P.M, BATISTA-ARTEAGA M, SYMINGTON A, RAWLINGS N.C. (2004): Ultrasound and endocrine evaluation of the ovarian response to a single dose of $500 \mathrm{IU}$ of eCG following a 12-day treatment with progestogen-releasing intravaginal sponges in the breeding and nonbreeding seasons in ewes. Theriogenology. 61: 311-327.

DIXON A.B, KNIGHTS M, PATE J.L, LEWIS P.E, INSKEEP E.K. (2006): Reproductive performance of ewes after 5-day treatment with intravaginal inserts containing progesterone in combination with injection of prostaglandinF2a. Reprod Domest Anim. 41: 142-148.

DOGAN I, NUR Z. (2006): Different estrous induction methods during the nonbreeding season in Kivircik ewes. Vet Med Czech. 51: 133-138.

GODFREY, R. W., GRAY M. L. COLLINS J. R. (1997): A comparison of two methods of estrous synchronization of hair sheep in the tropics. Anim. Reprod. Sci. 47:99-106.

JAINUDEEN, M. R., H. WAHID AND E. S. E. HAFEZ. ( 2000): Ovulation induction, embryo production and transfer. In: reproduction in farm Animals, seventh ed (Ed. B. Hafz and E. S. E. Hafez). Lippincott Williams \& Wilkins, Philadelphia, pp. 405-409.

KNIGHTS M, HOEHN T, LEWIS P.E, INSKEEP E.K. (2001): Effectiveness of intravaginal progesterone inserts and FSH for inducing synchronized estrus and increasing lambing rate in anestrous ewes. J Anim Sci. 79: 1120-113

KOYUNCU M , OZIS ALTICEKIC S. (2010): Effects of progestagen and PMSG on estrous synchronization and fertility in Kivircik ewes during natural breeding season. Asian-Aust. J. Anim. Sci. 23: 308-311.

KUSINA, N. T., TARWIREI, F. HAMUDIKUWANDA, H. AGUMBA G. MUKWENA J. (2000): A comparison of the effects of progesterone sponges and ear implants, PGF2 $\alpha$, and their combination on efficacy of estrus synchronization and fertility of Mashona goat does. Theriogenology 53:1567-1580. 
NADERIPOUR H, YADI J, SHAD A.G.K, SIRJANI M.A. (2012): The effects of three methods of synchronization on estrus induction and hormonal profile in Kalkuhi ewes: A comparison study. African Journal of Biotechnology. 11:530-533.

ÖZBEY, O.AND ESEN, F. (2000): The effects of oestrus synchronisation and flushing on birth weight of lambs, growth and survival rates in Awassi ewes. Journal Veteriner Fakültesi Dergisi, Uludağ Üniversitesi.19:119-127.

PETROVIC P.M .(2007): Sustainable sheepbreeding (in serbian). Institute for Animal Husbandry, Belgrade, 256 p.p.

PETROVIĆ, P. M., RUŽIĆ MUSLIĆ D, CARO PETROVIĆ V, MAKSIMOVIĆ N. (2011): Influence of environmental factors on birth weight variability of indigenous Serbian breeds of sheep. African Journal of Biotechnology. 10: 46734676.

ROMANO, J. E. (2004): Synchronization of estrus using CIDR, FGA or MAP intravaginal pessaries during the breeding season in Nubian goats. Small Ruminant Research. 55:15-19.

ROSADO, J., SILVA E, GALINA M. A. (1998): Reproductive management of hair sheep with progesterone and gonadotropins in the tropics. Small Rumin. Res. 27:237-242.

SPSS for Windows, Rel. 20.0. 2012. Chicago: SPSS Inc.

WILDEUS S. (2000): Current concepts in synchronization of estrus: Sheep and goats. Sheep and Goat Journal of Animal Science. 77: 1-14.

THIEME O., KARAZEYBEK M., AZMAN A.M., UĞURLU A.(1999) : Performance of village sheep flocks in Central Anatolia. I. Growth of lambs. Turk J. Vet. Anim. Sci. 23: 467-474.Turk J. Vet. Anim. Sci. 24: 71-79.

TURK G, GUR S, SONMEZ M, BOZKURT T, AKSU EH, AKSOY H. (2008): Effect of exogenous GnRH at the time of artificial insemination on reproductive performance of Awassi ewes synchronized with progestagen-PMSG-PGF2alpha combination. Reprod Dome st Anim. 43: 308-313.

UNGERFELD R, RUBIANES E. (2002): Short term primings with different progestogen intravaginal devices (MAP, FGA and CIDR) for eCGestrous induction in anestrus ewes. Small Ruminant Res. 46: 63-66.

WILDEUS S. (1999): Current concepts in synchronization of estrus: sheep and goats. Proc. Am. Soc. Anim Sci. 38: 1-14.

YILMAZ M, ALTIN T.( 2011): Growth characteristics in lambs of estrus synchronized ewes in grower conditions. Turk. J. Vet. Anim. Sci. 35(6): 421-429. 